\title{
Nation Brands and the Politics of Difference
}

\author{
Alfonso Del Percio, University of Oslo
}

\begin{abstract}
This article documents the debates surrounding the policing of the brand "Switzerland." It demonstrates that debating nation brands - particularly within the framework of a state policy of economic expansion - seems to be about who gets to produce and consume the desires that nations are imagined to stand for as much as about who gets to capitalize on the imagined value that these nations seem to have in specific markets. I also argue that if brands effectively seem to be precious sources of added value that can be exchanged with other forms of capital, not everybody is considered to have equal access to this capital. Because of their capability to produce and naturalize hierarchies between commodities, nation brands - and the entire institutional apparatus within which they are anchored and regulated-have also to be understood as key technologies of a state infrastructure governing the distribution of capital under current capitalistic conditions.
\end{abstract}

n autumn 2013, while I was conducting fieldwork on governmental campaigns sustaining Switzerland's export activities abroad, the Swiss parliamentarians were adopting the so-called Swissness act. ${ }^{1}$ This was the culmination of seven years of deliberation, where politicians, lobbyists, marketing specialists, and consumer protection organizations had been discussing how to legislatively protect the brand "Switzerland" from foreign fakes. While there seemed to be a general consensus within the federal administration and the national parliament about what qualities a Swiss product represents - in an expertise presented by the state to the wider public, the Swiss nation brand was

Contact Alfonso Del Percio at the Center for Multilingualism, Department of Linguistics and Scandinavian Studies, P.O. box 1102, Blindern 0317 Oslo, Norway (a.d.percio@iln.uio.no).

Versions of this article have been discussed with Sarah Van Hoof, Alexandre Duchêne, Sari Pietikäinen, and Bianca Schmidli. I'm grateful for their questions, comments, and criticisms. These findings draw on research funded by the Swiss Research Foundation (SNF-FNS) titled "Performing Swissness: Discourse, Institutions and Social transformations" (SNF-100012 129885), jointly held by Alexandre Duchêne (University of Fribourg) and Vincent Kaufmann (University of St. Gallen). This work was also supported by the Research Council of Norway through its Centres of Excellence funding scheme, project number 223265.

1. This is the short name for the Trade Mark Protection Act.

Signs and Society, vol. 4, no. S1 (Supplement 2016). () 2016 Semiosis Research Center at Hankuk University of Foreign Studies. All rights reserved. 2326-4489/2016/04S1-0001\$10.00 
defined as consisting of the following qualia: exclusivity, innovation, high quality, culturally diversity (see Feige et al. 2013) — the main debates centered on which products would effectively be icons of the values embodied by the brand "Switzerland."

Switzerland is not new to such debates. The history of the national economy is full of events where the essence of what should be considered as being "Swiss made" has become the object of controversy. Both within the spaces of national policy making and within the guilds and fabrics of the national economy, the protection of this capital of distinction has historically been at the core of Swiss preoccupations. However, since-according to the former minister of foreign affairs - the existing Swiss and international trademark regulations were insufficient to fight the currently dramatic increase in illegal use of the brand "Switzerland," a new legislative framework needed to be developed and implemented.

These anxieties regarding the supposed misuse of national brands are not exclusive to Switzerland. These are preoccupations shared by many of those bodies, governments, and national industries that have been investing in nation brands to raise the exchange value of the national goods inhabiting this brand. By the same token, supranational organizations governing capitalism, such as the European Union (EU), also consider misuse of brands - and nation brands in particular - to be "a serious problem for anyone." These practices are meant to be "harmful" and "worrying," as they "reduce business and government revenues, stifle investment and innovation and hinder economic growth" (European Union 2015). As a consequence, along the lines of the EU's recommendation for the formulation of stricter national legislation enforcing property rights, the Swiss federal government decided that the brand "Switzerland" has to be controlled, monitored, and protected from misuse and counterfeiting - through federal legislation and national policy — for the good of the nation.

For scholars who, like me, are interested in the intersection between the state's investment in the cultural models of the nation and the governmental distribution of resources, taking the regulation and protection of the Swiss nation brand as an object of anthropological investigation is a way to examine how, why, and with what consequences the Swiss state creates differences between commodities that are imagined to have the right to be branded as Swiss and those that are not. This is why, in this article, I put forward an analysis of the debates, tactics, positioning, and controversies surrounding the policing of the brand "Switzerland." This involves first an analysis of the Swissness act - that 
is, of its emergence and of the strategies and tokens of expertise it mobilizes to define which commodities should count as Swiss and which should not. This also involves an exploration of the tensions that this regulation of the national brand brings with it - both within and outside the governmental spaces in which this act was debated - and, more particularly, a documentation of the attempts to contest the differences made by the act as well as a discussion of the interests underpinning these contestations.

\section{On Nation Branding and Nation Brands}

In the last two decades, branding, and nation branding in particular, has attracted the attention of practitioners and scholars celebrating these activities as powerful practices for enhancing the value, desirability, and competitiveness of a nation and of the commodities commercialized by its economies (Olins 2002; Dinnie 2008). While specialists disagree on whether nation branding is a simple advertising practice, a governmental strategy or a set of political economic measures and institutions (Anholt 2007), what all these imaginations of nation branding have in common is that, in times of accelerated economic globalization, the imagined identity of a given nation is conceptualized as a fruitful resource for the strategic marketization of a given locality (Kotler and Gertner 2002; Morgan, Pritchard, and Pride 2011). Indeed, nation branding has been assumed to generate a profit of distinction and to contribute to the attraction of capital, tourists, investors, and trade and, as such, to the formation of prosperous nations (Papadopoulos 2004). Nation branding has also been celebrated as a technique of transnational governmentality permitting the peaceful regulation of global decision-making processes (Van Ham 2001).

Nation branding has further attracted the interest of a critical scholarship exploring its semiotic and ideological nature (Moore 2003; Foster 2007; Manning 2010; Nakassis 2012, 2013; Cavanaugh and Shankar 2014). Starting from the assumption that authoritative knowledge on the nation is never neutral, researchers have focused on the tensions related to this promotional investment in ideologies of nationhood (Kaneva 2011a, 2011b). Scholars have particularly paid attention to how nations are semiotically enacted in marketing campaigns (Aronczyk 2013; Del Percio 2016). This scholarship has also documented how this commercial nationalism (Volcic 2009) contributes to the reproduction of cultural models of the nation hierarchizing individuals, their languages, and cultures, as well as contributing to the definition of the limits of how nations can be conceived (Volcic 2008). This also involves a focus on 
how the marketing campaigns and semiotic materialities (brochures, clips, stands, pictures, etc.) in which these nation brands become textually manifest and intertextually circulate across time and space are negotiated, designed, and produced within specific institutional frameworks (Aronczyk 2008; Del Percio 2014; Duchêne and Del Percio 2014). Also involved is a problematization of how nation brands become invested to exert control over both the way specific publics perceive the branded nations (Jansen 2008; Shankar 2012; Del Percio 2015) and the way citizens and laborers that have to embody and represent the qualities iconized by these nation brands act and think (Coombe 1996; Lorente 2007; Petruseva 2012; Graan 2013).

Scholars have also examined how nation branding is invested to practically produce and legitimize relations of domination between nation states (Harvey 2005). In times of accelerated liberalization in which postcolonial countries, postcommunist states, and third-world countries compete with former colonizing and imperial nations for access to primary resources, capital, and consumers, nation branding represents a powerful technique of communicational persuasion (Snow and Taylor 2006). Indeed, it permits reference to be made to historically established forms of authority, that is, symbolic formations pointing to long-standing ideological assumptions about the supposed cultural and moral superiority of certain (Western) nations and their commercialized goods and services (Plaisance 2005; Wang 2007). Nation branding - especially in postcommunist countries - also permits the formulation of alternative (i.e., supposedly morally superior and more acceptable) imaginations of national pasts (Dzenovska 2005). This also enables these states to align their reinvented state histories with the imagined ones of those (Western) countries standing for (post)modernity, prosperity, and democracy - all qualities that under current capitalistic conditions are meant to attract the desire of potential investors and tourists, and other sorts of capital (Loo and Davies 2006; Kaneva 2007). As such, nation branding, it has been said, facilitates the reproduction of old hierarchies as well as the establishment of new ones between national actors that today compete within a new, deregulated world system (Roy 2007).

While this entire body of literature has particularly focused on how, why, and with what consequences for whom nation states get branded, in this article, I rather focus on the nation brands themselves - that is, on powerful signs that are imagined (by states and marketing specialists) to create value by inhabiting, and at the same time capitalizing on, the affective attachments that a given market demonstrates to the reputation of a given country (see Nakassis [2012, 2013] for similar claims). More particularly, I explore the political economy (Del 
Percio, Flubacher, and Duchêne, forthcoming) of the Swiss nation brand. This involves the infrastructures, that is, the institutions, the mechanisms, and the dynamic and sometimes contradictory activities that define which commodity is considered to be legitimately branded as Swiss and that justify access to or exclusion from the practices that a capital nation brand often comes with (such as public funds, public supply contracts, promotional campaigns, state service support of export projects, along with privileged access to niche markets and networks of stakeholders).

In order to do so, in the following sections I first turn to analysis of the Swissness act. I explore in particular the process through which specific qualities associated with the imagined Swiss nation brand are extended to specific products to distinguish between commodities that are considered to be legitimately branded Swiss from commodities that are not. I particularly focus on the cultural assumptions, systems of classification, and taxonomies that are invested to legitimize these practices of differentiation. I then move to an analysis of the tensions and struggles that the deliberation of this act engendered, that is, to documentation of the different forms of contestation of the differences produced by this specific act. This also involves questioning of the strategies and interests these contestations serve.

The analysis put forward in this article will draw on institutional texts entextualizing the legislative processes leading to the adoption of the Swissness act. This includes textual data such as legislative texts, parliamentarian minutes, reports, and position statements by several political parties, local municipalities, and industrial unions, as well as newspaper articles commenting on these debates occurring within the structures of the Swiss federal administration.

These data will enable me to highlight the discursive strategies deployed to iconize specific links between certain qualia and certain products that are then imagined to be Swiss and consequently legitimately branded as Swiss (Irvine and Gal 2000; Gal 2013). The data will also enable me to point to the multiple strategies and enactment of expertise mobilized by several actors to legitimize their positioning toward the links and differences imposed by the federal law regulating access to the brand Switzerland (Silverstein and Urban 1996). Finally, the data will help me to understand the interests, tactics, and logics regulating the investigated processes and debates (Bourdieu 1984).

\section{Policing National Brands}

In 2006, two parliamentarians from the liberal Social Democrats and the conservative Swiss People's Party launched two parliamentarian interpellations ask- 
ing the national government to propose strategies for the protection of the brand "Switzerland" (Marke Schweiz). While defending diverging interests and addressing different audiences, one year before the renewal of the national parliament, these two leading national parties identified the protection of the brand "Switzerland" as an ideal terrain of political capitalization. The Social Democrats claimed that a protection of the Swiss nation brand would imply a preservation of jobs in Switzerland and protect consumers from fraud and exploitation, while the representative of the Swiss People's Party highlighted the need to ensure the Swiss export economy's competitive advantage when entering the global market. Both political actors justified their interpellations with the necessity to protect what they imagined to be a national capital from foreign illegitimate appropriation. Indeed, both interpellations were constructed by their authors in reaction to the supposed increasing abusive usage of the Swiss nation brand by economic actors who had unduly exploited the good reputation of Switzerland-that is, who had marketed their products as Swiss while producing and processing these commodities outside the national borders or relying on foreign primary resources and labor force.

These interpellations were a powerful way to attract the desire and attention of a public made up of voters and industrial sponsors (of political campaigns) concerned with the effects of a globalizing world economy, in terms of increasing transnational competitiveness, accelerated delocalization of the productive activities, and the employment and globalization of consumption practices. The regulation of the companies' access to the brand Switzerland was also welcomed by all those actors and offices of the Swiss federal administration who were mandated to provide economic and financial incentives to those Swiss enterprises and industries affected by the deregulation of the global markets. These offices are particularly meant to support the Swiss economy in their export activities and to distribute certificates of origin and quality, giving the Swiss companies a competitive advantage in both domestic and global markets. Indeed, what all these offices and sections of the Swiss state have in common is the bureaucratic need for clear and legally authorized instructions helping them to differentiate between Swiss and non-Swiss companies. These instructions were imagined to legitimize the distribution of state-sponsored resources dedicated to the development and protection of the Swiss economy.

These two interpellations gave rise to seven years of debates, productions of expertise, statements, reports, deliberations, and consultations within and outside the institutional spaces of the Swiss federal administration. The question that was at the center of the debate was how much Switzerland had to be in the 
products branded as Swiss. This question was explosive. Most of those commodities that are considered by the wider public as Swiss - such as chocolate, cheese, and watches, as well as services in the domain of banking and financeand that have been capitalizing on the imagined prestige of the "Switzerland" brand, were accused by the consumer protection organization, Swiss unions, and the community of Swiss small- and medium-sized enterprises of being produced outside Switzerland, by non-Swiss laborers, and of consisting primarily of resources imported from abroad. This is why, in its Swissness act, the Swiss government proposed a list of criteria defining which products should count as Swiss - that is, which commodities should have the right to be branded as Swiss and to capitalize on the surplus value this nation brand supposedly endows.

In what follows, I examine how the Swissness act distinguishes between Swiss and non-Swiss commodities by producing classes and subclasses of products with specific qualities and by demanding different degrees of Swissness as a condition of access to the brand Switzerland. The piece of data that I will discuss is part of the Swissness act that was adopted by the parliamentarians in autumn 2013. This sixteen-page-long legislative document regulates in detail the protection of the brand "Switzerland."

Article 48. Indications of source for goods

1. Indications of source for goods are considered to be correct if the requirements under Articles $48 \mathrm{a}-48 \mathrm{c}$ are fulfilled. . . .

4. The place of origin or processing for Swiss indications of source for natural products and foodstuffs is the Swiss territory and customs union areas. The Federal Council may define the border areas, which are exceptionally considered as the place of origin or processing for Swiss indications of source.

Article $48 a$. Natural products

The origin of a natural product corresponds:

a. for mineral products: to the place where they were extracted;

b. for plant products: to the place where they were harvested;

c. for meat: to the place where the animals spent the predominant part of their lives; 
d. for other animal-derived products: to the place where the animals were kept;

e. for products of hunting or fishing: to the place where such hunting or fishing was carried out;

f. for farmed fish: to the place where they were reared.

\section{Article 48b. Foodstuffs}

1. Foodstuffs within the meaning of the Foodstuffs Act of 9 October 19923 (FSA) fall under this provision, with the exception of natural products under Article $48 a$ of this Act.

2. The origin of a foodstuff is the place from which at least 80 per cent of the raw material weight that makes up the foodstuff comes. For milk and dairy products, the weight of milk as the raw material must equal 100 per cent.

3. Excluded from the calculation under paragraph 2 are:

a. natural products which, due to natural conditions, cannot be produced at the place of origin;

b. natural products that are temporarily not available in sufficient quantities at the place of origin.

Article $48 c$. Other products, in particular industrial products

1. The origin of other products, in particular industrial products, corresponds to the place where at least 60 percent of the manufacturing costs are incurred.

2. For the calculation under paragraph 1, the following shall be taken into account:

a. production and assembly costs;

b. research and development costs;

c. costs for quality assurance and certification which are prescribed by law or standardised in an economic sector.

3. Excluded from the calculation under paragraph 1 are:

a. costs for natural products which, due to natural conditions, cannot be produced at the place of origin; 
b. costs for raw materials which, in accordance with an ordinance under Article 50 paragraph 2, are not available in sufficient quantities at the place of origin for objective reasons;

c. packaging costs;

d. transport costs;

e. the costs for distribution of the goods, as well as costs for marketing and customer service.

4. In addition, the indication of source must correspond to the place where the activity, which gave the product its essential characteristics, took place. In all cases, an essential manufacturing step must have been carried out at this place.

Article 49. Indications of source for services

1. The indication of source of a service is considered to be correct if:

a. it corresponds to the registered office of the person providing the service; and

b. a place of effective administration of this person is located in the same country.

3. Any additional requirements such as compliance with prescribed or customary principles of providing the service or the traditional association of the person providing the service with the country of origin must also be fulfilled. ${ }^{2}$

A closer analysis of this text enables us to make the following considerations:

1. These two legislative articles are distinguishing between classes of commodities. The first differentiation is between "goods" and "services." The federal act further imposes three subclasses for the class of "goods": "natural products," "foodstuffs," and "industrial products." Moreover, this text subdivides the subclasses into further subclasses, differentiating the "natural products" into mineral, vegetable, and meat-based products; meat-based products are again differentiated between elevated and selvage meat and fish. The subclass "foodstuffs" is subdivided into normal foodstuffs, milk and dairy products, products that cannot

2. This an excerpt from the official English version of the Trade Mark Protection Act. 
be produced in Switzerland, and products that for specific reasons are temporally not available in Switzerland.

These classifications are legitimized and authorized by their interdiscursive links to taxonomies and systems of classification defined within the framework of existing national legislations such as the Federal Act on Foodstuffs and Utility Articles and the Federal Customs Law. These classifications also draw on legislative regimes imposed by supranational organizations governing current capitalism such as the World Trade Organization, the World Health Organization, the Organization for Economic Co-operation and Development, the European Union, and other supranational bodies. These pieces of legislation in turn entextualize (modern) relations of difference that have historically served Western governments to structure social life and govern economic exchanges. These are imagined differences between the material and the symbolic that authorize here the differentiation between goods and services; these are cultural assumptions on the essence of things and on how this essence becomes alienated and transformed through human processing, assumptions that legitimize the subdivision of the category of goods according to their degree of processing (natural products, foodstuffs, industrial products). These classifications are also biological taxonomies justifying the differentiation between mineral, vegetable, and animal. They are long-standing assumptions about the difference between nature and culture allowing distinction between meat from farmed animals and meat from hunted ones.

2. These classifications have effects on how the Swiss nature of the single commodities is defined and measured. Indeed, for every class (goods and services) and subclass (natural products, foodstuffs, industrial products), a different degree of Swissness is requested, the degree of demanded Swissness typically being measured by the degree of relatedness to an imagined Swiss territory shown by a specific commodity. However, the clue here is that what is actually meant by relatedness to the Swiss territory varies according to the different categories and subcategories. The natural products, for example, have to be raised, caught, gathered, and fished on Swiss territory. The animals whose meat is commercialized as Swiss need to have spent the majority of their lives in Switzerland. In the case of the foodstuffs subcategory, Swissness depends on the origin of the ingredients they are made of: 80 percent of their weight has to consist of resources originating from Switzerland. But this again is not meant for all foodstuff. Indeed, milk and milk products have to be entirely (100 percent) from Switzerland. In contrast to that, products that do not grow in Switzerland - either 
temporarily or permanently - are not part of this calculation. For the industrial products, a new marker of Swissness is introduced: the costs. Sixty percent of the costs emerging by producing a certain commodity have to be incurred in Switzerland. But here as well differences are made between costs: not all costs are equal. There are useful costs and nonuseful ones - that is, costs that one can capitalize on and others that cannot be mobilized to claim access to Swissness. Good costs are costs related to the fabrication process, to research and development, and to quality control and certification. Noncreditable costs are costs for the commercialization and marketization of products, transport costs, packaging costs, and costs arising for ingredients that are not available on the Swiss territory. Finally, the Swissness of a given service depends on the place of the headquarters of the company (here person means juridical personality that denotes the company) providing a service as well as the place of the actual administration of the company. The degree of Swissness of these services is also dependent on their compatibility with an imagined business culture and the capability of the company providing these services to be recognized as traditionally belonging to the imagined community of the national economy.

In other words, these two articles act as a script - that is to say, a set of institutionally codified instructions that define the degree of iconicity of a given commodity with the abstract qualities represented by the Swiss nation brand (see, e.g., Gal [2013] and Lorente [forthcoming] for a discussion of the powerful nature of such scripts). This similarity is mediated on the one hand by ideologies of nationhood, these being cultural assumptions that impose the principle of territoriality as the absolute condition by which the Swissness of every commodity is measured. On the other hand, this similarity is mediated by a whole set of other classifying assumptions on the nature of a given commodity that define what the principle of territoriality concretely implies (e.g., the place where the costs of the fabricated commodity are incurred; the place of harvest; the locus of elevation of animals or of the capture of animals, etc.).

The clauses, percentages, and exceptions regulating the validity of the principle of territoriality as a marker of Swissness are the result of the yearlong pressures to which the federal authorities and the parliamentarians that have adopted the law were exposed. Indeed, during the definition process of these codified instructions, the main stakeholders - that is, the members of the national economywere asked to comment on several drafts of the document and to propose changes that were suitable for their economic activities in the global market. Groups of lobbyists and so-called practitioners from different sectors of the national indus- 
tries were invited to give expert input. As one of the parliamentarians put it, these instructions were the product of a tension between the industries' promotional wish to continue capitalizing on the capital of distinction represented by the Swiss nation brand and their economic necessity to do it at the lowest cost possible.

Indeed, while the policing of the national brand was meant to be a means to protect an imagined national capital of distinction from uncontrolled and illegitimate appropriation by actors who do not stand for the values that are represented by the Swiss nation brand - which, it was imagined, would lead to a loss of the public's trust in the brand "Switzerland" and to a decrease of its value in the international markets - this regulation also involved a risk: namely, that those actors who for many decades had legitimately capitalized on this brand "Switzerland" would, because of the tightened regulation, need to accept the emergence of additional costs to meet the new Swissness criteria or lose access to this capital of distinction. Therefore, instead of profiting from a stricter regulation, these national entrepreneurs would become victims of the regulation.

This is why the introduction of a whole taxonomy of classes and subclasses regulated by distinctive logics and rules governing access to the brand "Switzerland" should be explained by the governmental necessity to create a model giving justice to the multiple and heterogeneous demands of the national economy and, at the same time, the interests of the politicians to respond to the Swiss voters' demand for more Swissness: that is, more Swiss jobs; support of the local economy; more genuine, healthy, and local products and goods; more tax revenues from local production; reduced ecological footprints through transport and storage - all claims that were, of course, also associated with claims for further restrictions in terms of diversification of the Swiss society as well as globalization of foods and consumption habits.

Now, despite the many clauses and exceptions, the federal act continued to create tensions both during its deliberation within the parliamentarian chambers and after its adoption. In the next sections, I focus on these tensions and more particularly on the practices of resistance produced by two actors-Swatch, which is one of the world's leading watchmakers, and the city of Geneva, the major economic center in French-speaking Switzerland-that in one way or another felt disadvantaged by the way the new policy regulated the appropriation of the Swiss nation brand and therefore aimed to influence the parliamentarian deliberation on the federal act from outside the parliamentary chambers. These specific cases are to a degree emblematic, since they represent two extreme positions that repeatedly emerged in the debates both within and outside the federal parliament: namely, one claiming that the federal law is too restrictive in the 
way it defines a Swiss commodity, the other criticizing the law for not being restrictive enough.

In the following section, I document these contestations and analyze the discursive strategies (entextualized ideologies of the Swiss nation and its history) and semiotic resources (e.g., bits and pieces of Swiss German dialect, flags, and other tokens of banal nationalism) that are mobilized to legitimize these contestations. This also implies a questioning of what is at stake for those actors contesting this law - that is, what interests, strategies, and agendas these contestations of the Swissness act stand for.

\section{Protecting a Capital of Distinction}

One of the strongest voices in the deliberations on the Swissness act was that emanating from the Swiss watch industry, which has historically capitalized on the Swiss nation brand. Indeed, the Swiss flag, the slogan "Swiss made," and other tokens of the Switzerland brand have traditionally served the Swiss watch industry as capitals of distinction - that is, as powerful resources positioning the Swiss watches as particularly innovative, exclusive, and of high quality. However, according to representatives of the Federation of the Swiss Watch Industry in the national parliament, ${ }^{3}$ the counterfeiting of Swiss watches, and particularly the appropriation of the Swiss nation brand by supposedly foreign watchmakers, has attained alarming proportions and is endangering the existence of thousands of jobs in Switzerland. In order to defend its monopoly over the Swiss nation brand and to assure its competitiveness in the global markets, the Federation of the Swiss Watch Industry has been strongly invested in all phases of the design and deliberation of the Swissness act.

Now, just a few months before the adoption of the Swissness act in the parliament, a controversy broke out between Swatch — which has a leading role in the Federation of the Swiss Watch Industry - and Economiesuisse, which is the umbrella organization representing the Swiss economy. Economiesuisse was accused by Swatch of having lobbied for the softening of the criteria concerning industrial products, and more particularly for a reduction of the 60 percent clause to a 50 percent limit. This implied the possibility of relocating more productive activities to cheaper locations outside Switzerland while still being able to market the produced products as Swiss. This lobbyism was condemned by the watch giant as an unpatriotic act. Indeed, it was accused of representing evidence of the supposedly corrupt nature of that part of Swiss capitalism

3. The watchmakers are one of the best represented industrial sectors in the parliamentary chambers. 
that was represented by Economiesuisse, and it was claimed that, through its politics of transnational expansion and relocation, it would continue making profits at the costs of Swiss values and Swiss jobs.

These tensions between Swatch and Economiesuisse were just one instance in a long chain of historical controversies between actors competing for power and visibility in the unions, organizations, and political spaces governing capitalism in Switzerland. Thereby the "good of the nation" was often invoked as a battleground to legitimize these actors' actions, criticisms, and claims for more or less state support and intervention; for a regulation or deregulation of the markets; for more or fewer fiscal incentives; for the attraction or exclusion of foreign investors; for the relocation of Swiss companies in so-called low-cost countries or for re-attraction of these industries to the Swiss territory; as well as for the facilitation or prevention of foreign entrepreneurs' implementation of companies on Swiss territory.

However, despite these long-standing tensions and frictions, it is important to understand that these disputes over 10 percent more or 10 percent less costs arising in Switzerland have to be resituated in a Swiss political economic context characterized by a recent partial deindustrialization of the Swiss national economy. The Swiss watch industry especially has in the last thirty years experienced dramatic restructuring, with small or mid-sized watch manufacturers having to close their activities or being bought up by big Swiss and non-Swiss multinationals. This is a phenomenon that in certain French-speaking regions of western Switzerland in particular has resulted in depopulation and unemployment (see Flubacher and Duchêne [2012] and Duchêne and Flubacher [2015] for an extensive account of these restructures and transformations). Therefore, being for or against the 10 percent of costs generated in Switzerland was also a way of being for or against the watch industry in Switzerland and the preservation of labor and employment in impoverished regions of Switzerland. At least, that was how the tensions were framed by the actors participating in the debates.

To attract the public's attention to what the watch industry considered to be an act of arrogance toward the nation and to make sure that the pressures exerted by public opinion would force Economiesuisse to rethink its position, during the final deliberations on the federal law within the federal parliament in spring 2013, Swatch decided to intervene in the discussions through a marketing coup. Indeed, while the so-called Swiss GAAP FER norms regulating the accounting practices of Switzerland's enterprises ask the Swiss companies to produce their annual reports in German, French, and English, the German version 
of the annual report 2012 of Swatch ${ }^{4}$ was formulated in the Swiss German dialect, and not in that German that is considered to be the variety of written and formal communication in German-speaking Switzerland. Indeed, each of the twelve chapters that compose the annual report were formulated in one of the principal varieties that the umbrella term "Swiss German" is meant to subsume. Furthermore, on the cover page of the annual report, the producers of the document depicted the flags of the twenty-six Swiss cantons. In the section "Message from the Chair" that introduces the annual report, the CEO of Swatch legitimizes this choice as an act of loyalty toward the values "Verlasslechkeit, die hochi Qualitat i de Uusfuehrig, Intelliganz, aber hauptsachlech Villfalt, Eifachheit und Bescheideheit" (dependability, quality work, intelligence, diversity, simplicity, and modesty) that Switzerland is considered to stand for. It is also constructed as evidence of Swatch's concern with protecting the interests of the Swiss nation.

The use of the Swiss German dialect as a powerful semiotic resource to show the company's attachment to the Swiss nation was not by chance. It rather needs to be explained through Swiss German's historical role as an icon of Swiss national identity - that is, a resource belonging to all German-speaking Swiss and differentiating the imagined community of the Swiss from other German-speaking communities in other countries such as Germany, Austria, France, Italy, Luxembourg, or Belgium (see Watts [1988, 1999] for a more extensive account on what he calls the ideology of dialect in Switzerland). By the same token, the mobilization of the semiotic resource of the cantons' flags on the front page of the report displayed the company's attachment to another national symbol, namely, the political model of federalism that is represented by the cantonal flags and that, together with the local dialects, has historically been imagined in Switzerland as being unique to Switzerland. Federalism as an icon of the Swiss state is also believed to oppose Switzerland to the forms of imperial power and global capitalism represented by standard German and other tokens of centralized governance more generally. In order to prevent the non-German-speaking Swiss public from feeling alienated by this act of commitment toward Swiss German dialect as a national symbol — and to prevent this marketing coup being perceived as a challenge to another national symbol, namely, national multilingualismin "Message from the Chair," to gain the support of the other Swiss linguistic communities, the CEO also added: "Ich be mer secher, dass eusi Fründinne und Fründe us de Romandie, em Tessin und de rätoromanische Schwiiz de Uusdruck

4. The publication of Swatch's annual reports is usually accompanied by a highly mediatized press conference. 
vo eusere tüüfe Verbundeheit mit eusne Worzle schätze würde" (I am sure that our friends from the Romandie [French-speaking Switzerland], the Tessin [Italianspeaking Switzerland] and from the Romansch-speaking Switzerland will also appreciate our expression of deep attachment to our roots).

As intended by its producers, the Swiss German annual report has been largely discussed by the national (both German-speaking and French-speaking) and international media that effectively celebrated Swatch's choice as evidence of the company's dedication to Switzerland and the genuine and traditional values associated with the Swiss nation. All major national newspapers and radio and TV broadcasts reported on what was generally agreed to be a sympathetic and exemplary act of loyalty by a giant of the global watch economy toward Switzerland and its imagined values.

To understand the logic that at this specific time led Swatch to choose the Swiss German dialect for the German version of its annual report, I present a discussion of one of the many interviews that the CEO of Swatch, Nick Hayek, was asked to conduct to justify the use of the Swiss German:

There is indeed the idea in the business world that in a global company everything must be global, including its management, and that of the company's original roots nothing should shine through. We wanted to counter this idea with the Swiss German [version of the annual report]. We say that we are indeed a global player, but at the same time a typical Swiss company. From the beginning, Economiesuisse did not want to hear our arguments for more "Swiss made." For them, the reinforcement of "Swiss made" appears to be a weakening of the location, Switzerland. We have the impression that they [Economiesuisse] are driven by the fear that with a reinforcement [of "Swiss made"], fewer profits can be made. Apparently, the association [Economiesuisse] does not know that this label simply means trust for our customers abroad. Trust too can depend on the fact that if "Swiss made" is what is written on a watch, Switzerland is where it has been produced. ${ }^{5}$

In this excerpt from an interview given to the Swiss magazine Work (the magazine of Switzerland's major labor union), Hayek positions Swatch as a globally oriented organization rooted in national traditions. By doing so, Hayek

5. This interview excerpt was translated from German to English by the author. 
distinguishes his company from other globally oriented Swiss companies (which Economiesuisse is implicitly meant to stand for) that are supposedly managed by non-Swiss managers. Along those lines, Hayek constructs the mobilization of Swiss German as a means to stress his company's "urschweizerisch" (typically Swiss) nature. He also differentiates himself and his company from those Economiesuisse governed industries that prefer exchanging their Swiss positioning with a global orientation and as such lose their Swiss roots. Furthermore, Hayek constructs a link between the mobilization of Swiss German and the company's political engagement for more "Swiss made" and for a protection of the national brand more generally. Caring about the Swiss nation brand, as he and company are doing, is caring about those (imagined) Swiss values that both Swiss German dialect and the Swiss political model are meant to stand for. Here again the opposition that he creates between those actors who invest in what he calls "more 'Swiss made" and those who supposedly do not is a way to delegitimize Economiesuisse's status as a partner in the political decision-making process.

However, this excerpt also makes clear that Hayek's investment in a federal law restricting the use of the national brand is not exclusively for the good of the nation, as was generally claimed by the representatives of Swatch-that is, it was not just a way to contrast the delocalization of the national manufacturing industry with the consequent loss of jobs and national prosperity. The contestation of Economiesuisse's attempts to soften the restriction imposed by the Swissness act was also a way to protect a semiotic capital that for many decades had created the conditions of Swatch's international success. As Hayek explains, for the watch industry, a stricter handling of the brand "Switzerland" does not, as claimed by Economiesuisse, necessary imply the preservation of a national capital at the expense of profits. Investing in a major regulation of the Swiss nation brand was, according to Hayek, a means to invest in customer confidence - that is, an investment in the reproduction of the illusion of national authenticity, manufacturing tradition, and high quality that the promise of "Swiss made" stands for - and an investment in the long-term revenues and gains that this costumer confidence is imagined to represent. So, for him, investing in a strict regulation of the Swiss national brand was a means to protect a competitive advantage that was considered to be the source of his company's international success and leadership.

This attempt to influence the decision-making process by publicly construing Economiesuisse as a nonpatriotic economic giant was successful. Indeed, as a reaction to this media campaign conducted by Swatch, Economiesuisse in- 
structed its representatives in the parliament no longer to oppose the 60 percent costs clause for industrial products. They were asked to accommodate the interests of those economic actors such as Swatch that were arguing in favor of a stricter regulation of the national brand. This decision by Economiesuisse, together with the Swiss parliamentarians' need not to be associated in an election year with those parts of the Swiss economy that had been constructed by Swatch as exchanging Swiss values and Swiss jobs for profits and economic growth, created the political conditions for a consensus in the national parliament and for the adoption of the act.

Despite this consensus, in the months following the adoption of the act, the legislative text continued to raise tensions with new actors contesting the way the act regulated the Swiss nation brand's appropriation and capitalization. Indeed, while the controversies documented in this section turned around the question of how much Switzerland has to be in a commodity that is branded Swiss, in the discussions conducted on the formulation and consultation of the ordinancethat is, the legislative text that regulates the interpretation and practical implementation of the Swissness act - a new question emerged: what do we mean by Swiss territory?

To understand how and why the policing and protection of the brand "Switzerland" resulted in tensions about what we mean by Switzerland and to explain what was at stake for those contesting the regulations, in the next section I would like to focus on the practices of resistance produced by different political and economic actors from Geneva, which, as mentioned, is the major economic center in French-speaking Switzerland.

\section{Swiss Milk from French Cows?}

As mentioned in the previous sections, one of the main principles defining the legitimacy of entrepreneurs to brand their commodity as Swiss was the principle of territoriality that is anchored in the Swissness act as stated in Article 48, paragraph 4: "The place of origin or processing for Swiss indications of source for natural products and foodstuffs is the Swiss territory and customs union areas. The Federal Council may define the border areas, which are exceptionally considered as the place of origin or processing for Swiss indications of source."

The act's definition of what, territorially, counts as Switzerland was considered problematic, especially for all those so-called zones franches, or dutyfree zones, situated in areas bordering France, Germany, Lichtenstein, Austria, or Italy where Swiss entrepreneurs have for decades developed institutional- 
ized cross-border economic activities, both in terms of close collaboration with economic actors operating from the other side of the borders and in terms of conducting productive activities on bordering soil. Among the historically and economically most significant duty-free zones are the "zones franches genevoises." This is the border area of around 547 square kilometers situated around Geneva, where Swiss entrepreneurs historically used to conduct business with their French colleagues on the other side of the border. For the greater part of the national agricultural sector, the adoption of the Swissness act was good news, because the imagined strengthening of the brand "Switzerland" enabled the protection of Swiss products that are marketed as local - that is, more genuine, healthy, and of higher quality - from the increased competition of cheaper European agricultural commodities. Because of the liberalization of the European markets, these foreign products were often considered by Swiss farmers as unfair competition and as a threat to the existence of the local agricultural economy. However, for the entrepreneurs who operated in the zones franches genevoises, and especially for the entrepreneurs in the agricultural sector, the adoption of the Swissness act was considered a risk. Indeed, by excluding the zones franches genevoises from the territory that was considered to belong to Switzerland, for certain industries operating in these zones franches, the Swissness act meant loss of access to the brand "Switzerland" and consequently loss of privileged access to the Swiss market.

One of these industries was the Laiteries Réunies de Genève, a cooperative of ninety small local farms active in the production of milk and cheese that are distributed both in the Swiss territory and in the French territories. The Laiteries Réunies de Genève employs around 400 workers and is one of the main milk providers of the region of Geneva; ${ }^{6}$ in particular, it provides its products to the main grocery chains - Migros, Coop, and Manor-operating in that area. The farmers who own the small farms that make up the Laiteries Réunies de Genève had traditionally allowed their animals to graze on fields situated only a few hundred meters on the other side of the national border. At the same time, they commercialized their products as Swiss and capitalized on the surplus value that comes with the Switzerland brand. This is why the adoption of the Swissness act - which, as we have seen, defined the principle of territoriality as an axis of differentiation regulating access to the national brand - put this practice in danger. No longer having the possibility to brand their milk as Swiss was considered

6. This figure includes both farmers and the labor force working in the administration of the cooperative and the distribution and commercialization of the produced goods. 
an existential risk by the dairies. Since the new regulation would have prevented the cooperative from using the Swiss nation brand for marketing purposes, this would have excluded them from having access to the sales market represented by the three big grocery chains.

The risk of the cooperative's exclusion from having access to the Switzerland brand and to its principal market more generally (Laiteries Réunies de Genève was not considered to be competitive enough on the French market because of the cheaper production conditions under which the French milk industry operates) meant that different economic actors and Geneva's local government felt the need to openly contest the Swissness act. They decided to urge the federal government through different resolutions and diplomatic interventions to include in the ordinance that regulates the implementation of the Swissness act an exception making sure that the industries operating in the zones franches genevoises could continue capitalizing on the brand "Switzerland." More particularly, by making reference to the last sentence of Article 48, paragraph 4, of the act, which explained that it is the federal government's right to define what counts as Swiss territory, Geneva's representatives asked the federal government to include a further exception in the act. Indeed, these actors asked for a similar exception to the one that had been found for those territories outside Switzerland that are considered to belong to the customer area of Switzerland, for example, the territory belonging to Lichtenstein, which is an independent Germanspeaking state situated at the eastern border of Switzerland between Switzerland and Austria.

What was at stake for Geneva's local government and economy was not only the continuation of the Laiteries Réunies de Genève and the 400 jobs that, as mentioned by the cooperative's management, were at risk in the case of the cooperative's exclusion from access to the Swiss market and the three big grocery chains more generally (these chains sell only milk that they can brand as Swiss). The implementation of the Swissness act and, more particularly, the restrictions and forms of national protectionism this law came with, was perceived as endangering the formation of the alternative transnational, political, economic institutionalized cooperation that Geneva had started to imagine with its political and economic partners on the other side of the national border. Indeed, since the late 1970s and, more concretely, since 2010, Geneva, together with the French authorities, invested in the formation and institutionalization of a transnational agglomerated area called Grand Genève. This included 211 municipalities situated both in the Swiss cantons Vaud and Genève and in parts of the French region 
Rhône-Alpes (and especially the department Haute-Savoie). Grand Genève was meant to create the conditions for a prosperous economic development of the region as well as a harmonious management of the social and environmental challenges that the twenty-first century is considered to embody.

This is why to protect this - in Europe - widely celebrated and prized agglomeration project and the 400 jobs that risked disappearing in the case of Laiteries Réunies de Genève's bankruptcy, Geneva's union of the agriculture industry (AgriGenève) and Geneva's local government decided to affect the decision-making process - that is, to make sure that all farmers producing in the zones franches genevoises, both on Swiss and on French territory, could continue to brand their milk as Swiss and so get access to the major chains of distribution in Switzerland.

While these practices of contestation were produced by different actors, through different communicational channels and textual genres - political resolutions, letters addressed to the French-speaking representatives of the federal government, forms of lobbyism by political and industrial delegations received in the Swiss federal administration, media texts and interventions - the discursive resources on which all these different actors relied are entextualized by the following excerpt from an interview that the director of AgriGenève gave to one of the major French-speaking Swiss newspapers.

We fear that, from Bern's perspective, the importance of these areas for the agricultural economy of the region and their historical roots have either been misunderstood or forgotten. It was in the thirteenth century that the first franchises were implemented to ensure the supply of Geneva, which at that time was landlocked and without territory. The regime of free zones that continues today was created two hundred years ago. The import quotas from these zones were removed by the arbitral award of Territet, which dates from 1933. This international agreement is a Genevaspecific arrangement that, let's remember, has a $103 \mathrm{~km}$ border with France. Agricultural trade activities with the neighboring French departments are intense. These activities have recently been further enhanced institutionally with the birth of the France-Vaud-Geneva agglomeration project, called Grand Geneva. ${ }^{7}$

7. This interview excerpt was translated from French into English by the author. 
To justify why the zones franches should be considered as one of the exceptions that the Swiss federal government should include in its definition of what counts as Swiss territory, the leader of Geneva's agricultural industry makes reference to three imagined historical characteristics determining the status of Geneva in Switzerland. First, the director of AgriGenève makes reference to Geneva's historical exception. Since Geneva was one of the last cantons that joined the federation of states that form contemporary Switzerland, ${ }^{8}$ Geneva has historically been accorded a special status in terms of political autonomy and selfgovernance, the zones franches genevoises representing one emblematic token of this special treatment.

Second, the director points to the geographically decentered location of Geneva in the extreme southwest of Switzerland, which means that the entire region is culturally, politically, and economically strongly oriented toward France (and the global markets more generally), with whom Geneva shares 103 kilometers of borders, while the canton's border with the rest of Switzerland represent just a little bit more than ten kilometers. This makes the canton of Geneva almost a small enclave in France, which explains the transnational agglomeration project Grand Genève and the economic importance of the zones franches genevoises.

Finally, he makes reference to Geneva's imagined linguistic and cultural difference. Geneva's Frenchness supposedly distinguishes it from the other urban centers of Switzerland, most of them situated in German-speaking Switzerland, with whom Geneva is not just politically and economically in competition, but by whom Geneva, because of this linguistic and cultural difference, feels misunderstood and excluded - a miscomprehension that Geneva's authorities feel is reproduced by Bern's exclusion of the zones franches from their definition of Swiss territory.

Of course, these discursive resources mobilized by the director of AgriGenève - and, more generally, the persuasive strategies of the local authorities in which this line of argumentation was anchored - did not arise from nothing. They are rather intertextually linked to the imagined values which are at the base of and which legitimize Switzerland's political model. Indeed, Switzerland has been historically conceived as a federal polity, giving a maximum of power and autonomy to the local political authorities and the cantonal governments in particular. Indeed, since the building of a federal state was done at the

8. The political transformation in the early nineteenth century led to a separation of Geneva from the French ruled region of Haute Savoie to which it had historically belonged. 
expense of local cultural and political autonomy and independence of the ministates that Switzerland consists of, the modern Swiss state has invested in the principles of federalism, subsidiarity, and state multilingualism in order to balance the centralizing forces and the restructuring in relation of power and domination that a federal state necessitates.

So, by making reference to Geneva's supposed geographical, historical, and linguistic situation of periphery and marginalization within Switzerland, Geneva's political and economic authorities make reference to and capitalize on the key principles that underpin the foundation of the Swiss nation-state and that in this specific case are exploited to legitimize their claims. Now, in line with what happened in the case of the controversy between Swatch and Economiesuisse, Geneva's lobbyism was effective. Despite the fact that representatives of the federal government had repeatedly explained that, unlike the case of Lichtensteinwhich belongs to the Swiss customs union and which has the same laws on food and agriculture as Switzerland - the zones franches genevoises were on French territory and ruled by French law, the federal authorities finally accommodated the requests from Geneva's political and economic representatives.

The decision to include the zones franches genevoises in the list of exceptions was justified by the federal authorities by the need to create the conditions for general acceptability of the Swissness act and, more particularly, for the ordinance to implement it. Indeed, while in times of crisis and recession capitalizing on the prestige and surplus value that come with the Swiss nation brand would have represented a competitive advantage on the international markets, the new regulations restricting access to the Switzerland brand made this capital of distinction more expensive for the local economy. Furthermore, the Swissness act asked the national industry to invest in local resources and a local workforce-that is, in productive resources that are more expensive than in other low-cost countries - so that, paradoxically, part of the national economy preferred to reject these new regulations that were complicating their access to a national capital on which they had historically drawn. So, in spring 2015, in order to avoid further complication, the federal authorities decided to introduce into the ordinance a whole series of measures softening the restrictions that were defined by the federal law. One of them was the inclusion of the zones franches genevoises in the list of bordering regions that would be part of the Swiss territory.

\section{Nation Branding as a Technology of State Governmentality}

In this article, it was my intention to document the definition and contestation of an institutionally codified script defending the brand "Switzerland" from 
illegitimate counterfeiting and defining who gets to appropriate the Swiss nation brand and who does not. This specific case has enabled me to demonstrate that debating nation brands - particularly within the framework of a state policy of economic expansion - seems to be about who gets to produce and consume the desires that the nation is imagined to stand for as much as about who gets to capitalize on the imagined value that these imagined nations seem to have in specific markets. This article also permitted me to argue that if brands effectively seem to be precious sources of added value that can be exchanged with other forms of capital, not everybody is considered to have equal legitimate access to this national capital. Because of their capability to produce, legitimize, and naturalize hierarchies between commodities, nation brands - and the entire institutional and legislative apparatus within which they are anchored and regulated-have also to be understood as key technologies of a state infrastructure governing the distribution of capital under current capitalistic conditions.

In consequence, the tensions and contestations that I have documented here represent the anxieties of those actors who fear that they will remain excluded from the distribution of resources represented by this redefinition of the rules regulating entrepreneurs' access to the brand "Switzerland." Indeed, as we have seen, the policing of a nation brand is not just a fancy marketing activity: it is rather a protectionist measure engaged by the Swiss state under conditions of institutionalized (neo)liberalism to give certain actors of the Swiss economy a competitive advantage in the globalized market.

The question that at this point remains open is, how will the Swissness actand, more particularly, the set of codified instructions this act entextualizesregiment entrepreneurs' access to the national brand and so produce inequality and hierarchies within the community of entrepreneurs in Switzerland and beyond?

What we need to understand is the future use of the Swissness act, and especially the concrete future interpretation of the codified instructions defining which entrepreneur producing which commodities can appropriate the national brand. An analysis of the Swissness act and of its deliberation and contestation is not sufficient to give an answer to how these instructions get invested by those institutions and individuals which will distribute the resources that the national brand represents.

We need rather to focus on the governmental institutions - such as the Swiss Federal Institute of Intellectual Property - that are mandated to control the ap- 
propriate use and investment of the Swiss national brand and that decide whether or not a commodity has the right to be branded as Swiss. We also need to explore the everyday work routines of those sections and offices of the Swiss federal government that support all those entrepreneurs producing commodities embodying the qualities defined by the Swissness act with the provision of resources (incentives, tax reductions, facilitated export conditions, support in the marketization and commercialization of commodities in the target countries) that the Swiss state provides under conditions of (imagined) economic crisis. Further, we need to question the work done by all those economic actors in the national and international target markets, such as distributors and brokers, who bring a specific commodity to the final consumers and who decide whether or not they are going to accept a commodity as Swiss and whether they identify the imagined Swissness of these commercialized goods as a source of added value that they are ready to pay for. Finally, we need to investigate the consumers themselves, who need to decide whether they recognize a commodity as Swiss and are ready to pay for the imagined qualities inhabited by the brand "Switzerland." In short, the next step would be to question the unpredictable practices of uptake of the Swissness act and its investment as an axis of differentiation legitimizing the distribution of resources.

In my ethnographic research conducted within the offices and sections of the Swiss state that support midsized Swiss companies in their export activities, I could, for example, observe that the criteria imposed by the Swissness act in terms of which product has the right to be branded as Swiss and which entrepreneur commercializing which products get the right to consume the services dedicated by the Swiss state to companies that commercialize Swiss products were not always equally interpreted. Depending on the available financial resources, the free capacity of the concerned embassies or consulates and the capacity of the entrepreneurs themselves to make sure that they get recognized as legitimate Swiss entrepreneurs that produce and commercialize legitimate Swiss commodities, the Swissness act's instructions were differently interpreted with different consequences for the entrepreneurs' capacity to gain access to the resources they were struggling to access.

This is why, in order to understand how, under which conditions, and with what consequences nation brands act as agents of difference, I argue here for an ethnographic investigation that resituates nation brands in their contexts of appropriation, exchange, and consumption - that is to say, an investigation that focuses on the circumstances that mean that certain actors can capitalize on this 
national capital and others cannot. This is also a call for a more serious consideration of the variable and sometimes contradictory nature of these processes and the tactics and strategies in which they are anchored.

\section{References}

Anholt, Simon. 2007. Competitive Identity: The New Brand Management for Nations, Cities and Regions. New York: Palgrave Macmillan.

Aronczyk, Melissa. 2008. "Living the Brand: Nationality, Globality and Identity Strategies of Nation Branding Consultants." International Journal of Communication 2:41-65.

. 2013. Branding the Nation: The Global Business of National Identity. Oxford: Oxford University Press.

Bourdieu, Pierre. 1984. Distinction. Cambridge, MA: Harvard University Press.

Cavanaugh, Jillian, and Shalini Shankar. 2014. "Producing Authenticity in Global Capitalism: Language, Materiality, and Value.” American Anthropologist 116 (1): 51-64.

Coombe, Rosemary. 1996. "Embodied Trademarks: Mimesis and Alterity on American Commercial Frontiers." Cultural Anthropology 11 (2): 202-24.

Dinnie, Keith, ed. 2008. Nation Branding: Concepts, Issues, Practice. Burlington: ButterworthHeinemann.

Del Percio, Alfonso. 2014. Capitalizing on National Diversity. PhD diss., University of St. Gallen. - 2015. "Le plurilinguisme suisse à l'ère du capitalisme tardif: Investissement promotionnel sur un capital national.” Anthropologie et Société 39 (3): 69-89.

- 2016. "Branding the Nation: Swiss Multilingualism and the Promotional Capitalization on National History under Late Capitalism.” Pragmatics and Society 7 (1).

Del Percio, Alfonso, Mi-Cha Flubacher, and Alexandre Duchêne. Forthcoming. "Language and Political Economy." In Oxford Handbook of Language in Society, ed. Garcia Ofelia, Flores Nelson, and Max Spotti. Oxford: Oxford University Press.

Duchêne, Alexandre, and Alfonso Del Percio. 2014. "Economic Capitalization of Linguistic Diversity: Swiss Multilingualism as a National Profit?" In Multilingual Encounters in Europe's Institutional Spaces, ed. Johann W. Unger, Michał Krzyżanowski, and Ruth Wodak, 77-103. London: Bloomsbury.

Duchêne, Alexandre, and Mi-Cha Flubacher. 2015. "Quand légitimité rime avec productivité: La parole-d'œuvre plurilingue dans l'industrie de la communication." Anthropologie et Société 39 (3): 173-96.

Dzenovska, Dace. 2005. "Remaking the Nation of Latvia: Anthropological Perspectives on Nation Branding." Place Branding and Public Diplomacy 2 (1): 173-86.

European Union. 2015. "A Serious Problem for Everyone," electronic document, http://ec .europa.eu/taxation_customs/customs/customs_controls/counterfeit_piracy/combating /index_en.htm.

Feige, Stephan, Benita Brockdorff, Karsten Sausen, Peter Fischer, and Urs Jaermann. 2013. Swissness Worldwide 2013. St. Gallen: Thexis.

Flubacher, Mi-Cha, and Alexandre Duchêne. 2012. "Eine Stadt der Kommunikation? Mehrsprachigkeit als wirtschaftliches Argument.” Bulletin Suisse de Linguistique Appliquée 95 : $123-45$. 
Foster, Robert. 2007. "The Work of the New Economy: Consumers, Brands and ValueCreation." Cultural Anthropology 22 (4): 707-31.

Gal, Susan. 2013. "Tastes of Talk: Qualia and the Moral Flavor of Signs." Anthropological Theory 13 (1-2): 31-48.

Graan, Andrew. 2013. "Counterfeiting the Nation? Skopje 2014 and the Politics of Nation Branding in Macedonia." Cultural Anthropology 28 (1): 161-79.

Harvey, David. 2005. A Brief History of Neoliberalism. Oxford: Oxford University Press.

Irvine, Judith, and Susan Gal. 2000. "Language Ideology and Linguistic Differentiation.” In Regimes of Language: Ideologies, Polities, and Identities, ed. Paul Kroskrity. Santa Fe, NM: School of American Research Press.

Jansen, Sue. 2008. "Designer Nations: Neo-liberal Nation Branding_-Brand Estonia." Social Identities. 14 (1): 121-42.

Kaneva, Nadia. 2007. "Meet the "New" Europeans: EU Accession and the Branding of Bulgaria." Advertising and Society Review 8 (4), http://muse.jhu.edu/journals/advertising _and_society_review/v008/8.4kaneva.html,

2011a. Branding Post-communist Nations: Marketizing National Identities in the "New" Europe. New York: Routledge.

- 2011b. "Nation Branding: Toward an Agenda for Critical Research." International Journal of Communication 5:117-41.

Kotler, Philip, and David Gertner. 2002. "Country as Brand, Product, and Beyond: A Place Marketing and Brand Management Perspective." Journal of Brand Management 9 (4/5): 249-62.

Loo, Theresa, and Gary Davies. 2006. "Branding China: The Ultimate Challenge in Reputation Management?" Corporate Reputation Review 9 (3): 198-210.

Lorente, Beatriz. 2007. "Mapping English Linguistic Capital: The Case of Filipino Domestic Workers in Singapore." PhD diss., National University of Singapore.

- Forthcoming. Scripts of Servitude: Language, Labor Migration and Domestic Work. Bristol: Multilingual Matters.

Manning, Paul. 2010. “The Semiotics of Brand.” Annual Review of Anthropologv 39 (1): 33-49.

Moore, Robert. 2003. "From Genericide to Viral Marketing: on 'Brand'." Lanquage \& Communication 23 (3-4): 331-57.

Morgan, Nigel, Annette Pritchard, and Richard Pride. 2011. Destination Brands: Managing Place Reputation. London: Routledge.

Nakassis, Constantine. 2012. "Brand, Citationality, Performativity." American Anthropologist 114 (4): 624-38.

. 2013. "Brands and Their Surfeits." Cultural Anthropology 28 (1): 111-26.

Olins, Wally. 2002. "Branding the Nation-the Historical Context." Lournal of Brand Management 9 (4-5): 241-48.

Papadopoulos, Nicolas. 2004. "Place Branding: Evolution, Meaning and Implications." Place Branding 1 (1): 36-49.

Petruseva, Ana. 2012. "Macedonians Behave! Tourists Are Coming.” Balkan Insight, May 18, http://www.balkaninsight.com/en/blog/how-low-can-you-go.

Plaisance, Patrick. 2005. "The Propaganda War on Terrorism: An Analysis of the United States' 'Shared Values' Public Diplomacy Campaign after September 11, 2001.” Lournal of Mass Media Ethics 20 (4): 250-68. 
Roy, Sinha. 2007. "Worlds Apart: Nation-Branding on the National Geographic Channel." Media, Culture \& Society 29 (4): 569-92.

Shankar, Shalini. 2012. "Creating Model Consumers: Producing Ethnicity, Race, and Class in Asian American Advertising." American Ethnologist 39 (3): 578-91.

Silverstein, Michael, and Greg Urban, eds. 1996. Natural Histories of Discourse. Chicago: University of Chicago Press.

Snow, Nancy, and Philip Taylor. 2006. “The Revival of the Propaganda State.” International Communication Gazette 68 (5/6): 389-407.

Van Ham, Peter. 2001. "The Rise of the Brand State: The Postmodern Politics of Image and Reputation.” Foreign Affairs 8 (5): 2-6.

Volcic, Zala. 2008. "Former Yugoslavia on the World Wide Web: Commercialization and Branding of Nationstates." International Communication Gazette 70 (5): 395-413.

2009. "Television in the Balkans: The Rise of Commercial Nationalism." In Television Studies after "TV": Understanding Television in the Post-broadcast Era, ed. Turner Graeme, 115-24. London: Routledge.

Wang, Jian. 2007. "Telling the American Story to the World: The Purpose of U.S. Public Diplomacy in Historical Perspective." Public Relations Review 33 (1): 21-30.

Watts, Richard. 1988. "Language, Dialect and National Identity in Switzerland." Multilingua 7(3): 313-34.

1999. "The Ideology of Dialect in Switzerland." In Language Ideological Debates, ed. Jan Blommaert, 67-103. Berlin: Mouton de Gruyter. 